\title{
The impact of the sustainable development dimensions on the quality of financial reports
}

\author{
Rizgar Abdullah Saber Jaff ${ }^{a}$, Farhad Rafaat Ali Al-Kake ${ }^{b}$ and Nawzad Majeed Hamawandy ${ }^{c^{*}}$
}

\begin{tabular}{l}
${ }^{a}$ Accounting Department - Salahaddin \\
${ }^{b}$ Accounting \& Finance Department, Co \\
${ }^{c}$ Department of Business Administration, \\
\hline C H R O N I C L E \\
\hline Article history: \\
Received: August 23, 2020 \\
Received in revised format: \\
October 302020 \\
Accepted: November 14, 2020 \\
Available online: \\
November 14,2020 \\
\hline Keywords: \\
Sustainable development \\
Quality of financial reports \\
Iraqi commercial banks
\end{tabular}

istration, Administration Technical College, Erbil Polytechnic University and Universiti Tun Hussein Onn, Malaysia

\section{A B S T R A C T}

\begin{abstract}
This study aimed at testing the potential impact of the disclosure of the main variables of sustainable development on the quality of financial reports, in a developing country, Iraq, where there is a lack of research in this area. To achieve its goal this study relied on an analysis of a sample from 91 financial reports of the Iraqi commercial banks listed on the Iraq Stock Exchange during the period 2012-2018. Our results prove that disclosure of the dimensions of sustainable development as a whole has a positive impact on the quality of financial reports in commercial banks in Iraq. The paper recommends conducting more research and studies on the dimensions of sustainable development in the future for other sectors such as industrial and service sectors linking it with other variables such as the cost of capital, or inconsistency of information.
\end{abstract}

\section{Introduction}

(C) 2021 by the authors; licensee Growing Science, Canada

Nowadays societies have to face two main problems. First the increase in pollution. Second, or natural resources shortly. Therefore, it is necessary to formulate a development model that preserves the existing natural resources to help future generations reducing the harmful waste and emissions through the implementation of what it is known as "sustainable development". The term sustainable development was adopted by the international community at the Earth Summit in Brazil in 1992. The 2015 United Nations Summit also emphasized the importance of sustainable development by working on economic growth with protecting social and environmental matters. Since then successive economic life developments have made it imperative for business organizations to adjust the economic models originally based exclusively on the maximization of profit, to take into account social and environmental dimensions. To determine the fair value of investments and to know the companies' performance by users of accounting information, many companies have disclosed all their information in various fields. This to improve companies' reputation within the society, and to ultimately ensure profitability and competitive advantage. In this way, the financial reports had to include an analysis of the economic, social, and environmental performance as well (Simnett et al., 2009; Malo-Alain et al., 2019). The disclosure of the sustainable development dimensions aims to make financial reports more reliable, transparence and comparable, which improves the quality of financial reports, and thus enables users of financial statements to assess the economic, social, and environmental impacts of the organization by identifying measurement items and discloser items (Moneva, 2006). This makes researchers more interested in the quality of financial reports because those reports have a significant impact on the decisions of users of financial statements, including investors (current and prospective),

* Corresponding author.

E-mail address: nawzad.hassan@epu.edu.iq (N. M. Hamawandy) 
financial analysts, customers, and suppliers. The quality of financial reports is an important matter for many of the agencies that depend on them in making their economic decisions. The general objective of financial reporting is to provide useful information to present potential investors, creditors, and others help them make investment, credit, and other decisions (Abdullah \& Jaf, 2015). The application of the accrual basis in the public sector makes financial reports highly transparent and provides a lot of information that makes financial decisions more accurate (Ahmed \& Al-Kake, 2019). The quality of financial reports is an important issue nowadays, due to the collapse of some American companies and the occurrence of the global financial crisis at the beginning of this century (Beest, 2009). Iraq has adopted a national strategy for sustainable development and the integration of environmental issues in the financial and services sectors, as a result of the country applied the national strategy for sustainable development in Iraqi banks (Jaf et al., 2019). The Association of Iraqi Banks held its fifth forum entitled "From social responsibility to sustainable development". This forum indicated that the disclosure of the dimensions of sustainable development as an indication of the level of success of the bank. The increased level of disclosure of this information shows a positive impression of the efficiency and effectiveness of the bank's performance among stakeholders. The disclosure of sustainable development will lead to an improvement in the quality of financial reports as well as to an increase in the market value of the company. Based on the aforementioned, the idea of this study came to test the effect of disclosing the dimensions of sustainable development on the quality of financial reports in Iraqi commercial banks. Clarify reliance on quantitative data that deals with readiness of banks for the information technology and their influence upon competitive advantages (Abdullah et al., 2011). The importance of the techniques of strategic planning in the role of information systems and information technology is increasing (Abdullah et al., 2011). Capital markets and the role it plays as an intermediary among investors and entrepreneurs has been given extra importance as the economic structures, policy and financial institutions rapidly improved under globalization (Hasan et al., 2019). panel-data techniques were employed to establish the impact of foreign direct investment in other countries, mostly the developed countries (Baban \& Hasan, 2019). Studies by Financial Reporting Council (2004) and HM Treasury (2002) have shown that effective internal and external audit roles in public sector governance are of paramount importance and have a huge bearing on major economic activities and hence have to be encouraged and promoted (Shezad \& Omar , 2020). Environmentally supportive behavior is a component of corporate social responsibility with a key focus on environmental management and sustainability (Ogiemwonyi et al., 2020). The Malaysian economy is growing fast within the structure of its mix of cultural modernization that is based on the religious concept (Ogiemwonyi \& Hamawandy, 2020).Further analysis showed that foreign direct investment has the positive impact on economic growth through knowledge spillovers in transition countries (Ibrahim, 2015).

\section{Research problem}

Banks seek to introduce the concept of sustainability in their goals and businesses, as the concept of commercial banks' responsibility has developed significantly at the beginning of the current century. Banks have become committed to contributing to sustainable development by working with employees, clients, shareholders, and society as a whole to improve the standard of living in a manner that achieves the goals of stakeholders and serves sustainable development simultaneously. Commercial banks face great pressure from stakeholders to improve the quality of financial reports and the information they contain because they need data and information to help them in their decision-making process. Consequently, the low quality of financial reports of these banks delivers false and unclear information, which affects the probity of stakeholders 'decisions. The interest in disclosing the dimensions of sustainable development along with other financial and non-financial disclosures is important for improving the quality of financial reports. This study aimed to test the effect of disclosure of the dimensions of sustainable development on the quality of financial reports in Iraqi commercial banks. The purpose of the study can be achieved by answering the following questions: -

1- Is there an impact of the disclosure of the economic dimension on the quality of financial reports in Iraqi commercial banks?

2- Is there an impact on the disclosure of the environmental dimension on the quality of financial reports in Iraqi commercial banks?

3- Is there an impact of the disclosure of the social dimension on the quality of financial reports in Iraqi commercial banks?

\section{Research objectives}

This research aims to test the impact of disclosure of the sustainable development dimensions on the quality of financial reports in Iraqi commercial banks and to achieve that, this study has the following goals: -

1- Knowing the concept of quality of financial reports, concepts, and measures.

2- Knowing the importance of disclosing the dimensions of sustainable development (economic, environmental, and social) in Iraqi commercial banks. 
3- Measuring the impact of disclosure of the dimensions of sustainable development (economic, environmental, and social) on the quality of financial reports in Iraqi commercial banks.

\section{The research importance}

This study is important because for the first time it focuses on sustainable development in Iraq's commercial banks. Sustainable development is required to contribute to building the society by fulfilling the economic, social, and environmental responsibilities towards the society to achieve a decent standard of living for the members of society at the present and in the future. The study is expected to help increase the interest of Iraqi commercial banks in disclosing the dimensions of sustainable development because of its positive effects on the quality of financial reports, and because of its impact on the decisions of current, prospective investors to attract them to invest in those banks and thus improve their reputation.

\section{Research hypotheses}

To achieve the aims of the study and to answer the research questions above, the research hypotheses were formulated as follows:

The main hypothesis: There is a statistically significant effect of disclosing sustainable development dimensions (economic, environmental, and social) on the quality of financial reports in Iraqi commercial banks. From which the following subhypotheses are derived:

The first hypothesis: There is a statistically significant effect of disclosing the economic dimension on the quality of financial reports in Iraqi commercial banks.

The second hypothesis: There is a statistically significant effect of disclosing the environmental dimension on the quality of financial reports in Iraqi commercial banks.

The third hypothesis: There is a statistically significant effect of disclosing the social dimension on the quality of financial reports in Iraqi commercial banks.

\subsection{Theoretical Framework}

\subsubsection{Sustainable Development}

One of the concepts that have received much attention is sustainable development and, due to the modernity and importance of this issue for enterprises, there has been a lot of research on the topic. Sustainable development has a significant contribution to increasing the efficiency of enterprises, which leads to raising the level of the economy in general, and enterprises in particular. This increasing of interest made a lot of definitions by scholars about the concept of sustainable development. In 2002, the Organization for Economic Co-operation and Development (OECD) defined sustainable development as development that includes integrating economic, social, and environmental goals for society to maximize human well-being today without compromising the ability of future generations to meet their needs. Aras and Crowther (2009) identified it as the effect of the establishment's activity on the internal and external environment of the facility and its impact on the future. According to Othman et al. (2019) organizations gain experience and knowledge from the external environment to strengthen their internal environment. Albu (2011) defined it as the conservation of resources through the integration of the components of the societal system which seeks to preserve the planet and the possibility of continuing life on it. Sustainable development includes three dimensions as defined by the World Summit on Sustainable Development in Johannesburg in 2002. These dimensions are economic, social, and environmental dimensions. The conference stressed that the effectiveness of sustainable development depends on synergy in these three areas and that each of those dimensions includes a group of activities that interact with each other to achieve sustainable development (Sebhatu \& Enquist, 2007). The dimensions of sustainable development are:

First: The economic dimension: This dimension reflects the effects of the activities of the bank on the economic systems at all levels and on the economic conditions and variables of the stakeholders. Thus, the impact of the economic dimension focuses on the economy in general (national, local, and global) as first and on all the parties associated with the company in economic terms as a second (GRI, 2006).

Second: the social dimension: This dimension aims to achieve social justice in the distribution of economic, natural resources, the development of cultures in societies, the promotion of equality, human rights, and the building of healthy community relations (Dixit et al., 2019). This dimension focuses on equity in distribution, grassroots participation, group, cultural diversity, and corporate sustainability. 
Third: The environmental dimension: The objectives of this dimension are focused on searching for renewable sources of resources, reducing the use of those that may be depleted, and providing protection for the ecosystems from land, air, and water. The most important elements of the environmental dimension are diversity, biological production, energy, ecosystems, and adaptability. Thus, the banks 'commitment to disclose their environmental performance indicates their awareness of environmental matters, and that the efforts made by the company in preserving the environment have positive repercussions on the existence and continuity of the bank.

Sustainable development information is disclosed in the form of sustainability reports, as these reports provide quantitative and descriptive information, financial and non-financial, and providing that information to stakeholders (Nawzad et al., 2019). There are several different forms and models for providing sustainable development accounting information and include performance reports, input and output analysis, lists of compliance with relevant legislation and regulations, and an economic, social and environmental impact narrative.

\section{Quality of Financial Reports}

Accounting information reflects accurately and fairly the true condition of the entity. Since the interest in the quality of financial reports has increased, the quality and relevance of the accounting information provided to its users have become very important (Al-kake \& Ahmed, 2019). Several studies have examined the effects of the quality of the financial reports and what the accounting information is contained. According to (Al-Kake, 2019) the independence of the internal auditor, which is an important part of internal control, has a positive impact on the quality of financial reports. One of the major motives behind changes in internal control is surrounded with vast activities of gross corporate misconducts (Mahmood et al., 2020). Furthermore, the effect of the publication of this information on the amendment of the future expectations by stakeholders in which they have interests with the corporation (Kevin \& Vicki 2008; Xio \& Min, 2011).

There are several patterns for measuring the quality of financial reports. The qualitative characteristics of information were used as a measure of the quality of earnings by (Cheung \& Wright, 2010; Beest et al., 2009), but this measure is difficult to use because these characteristics are difficult to measure. (Barth et al., 2008; Goel, 2012) used profit quality as a measure of the quality of financial reporting through management earnings as a measure of the quality of financial reporting. Studies of (Hu et al., 2014; Hamdan et al., 2011; Malo-Alain et al., 2019), were relied on the level of accounting reservation to measure the quality of financial reports, as it examined the role of reservation in improving information, by reducing the degree of non- identical information.

Based on the multiplicity of measures through which the quality of financial reports can be measured using the accounting retention measures, this study will be based on the use of the ratio of the market value to the book value (MTB) because it reflects the total reservation of the company and its ability for practical application.

\section{Research methodology}

This study relied on the descriptive approach of the collected data. It also relied on the analytical method through the analysis of data and testing hypotheses, to provide results and recommendations. The research methodology includes presenting the research population, sample, defining, describing research variables, and the study model.

\subsection{Research Sample}

The population of the study included all the Iraqi commercial banks listed on the Baghdad Stock Exchange. In total, the study analyses the annual financial reports of thirteen Iraqi banks issued between 2012 and 2018.

\section{Definition and measurement of variables}

First: the independent variable

The disclosure of the dimensions of sustainable development: the G4 general framework includes:

1. Items relating to the disclosure of the economic aspect, according to what was reported on the Global Initiative for Sustainability Report.

2. Items related to disclosure of the environmental aspect, according to what was reported on the Global Initiative for Sustainability Report. 
3. items related to the disclosure of the social aspect, according to what was reported on the Global Sustainability Report Initiative.

The method of content analysis was used in this research. No. 1 was placed if the bank disclosed the item, while the number 0 was set in the event of non-disclosure.

\section{Second: The dependent variable:}

The quality of financial reports: It is measured in terms of the level of the accounting reservation using the MTB model, and this model is based on measuring the reservation through the ratio of the market value of the net assets to its book value, according to (Hu et al., 2014; Hamdan et al., 2011; Malo-Alain et al., 2019; Laptes \& Sofian, 2016), MTB calculated by the following formula:

$M T B=$ Market value of equity / book value of equity.

The market value of equity = shares price at the end of the fiscal year $x$ number of ordinary shares outstanding.

Book value of equity = Equity based on the statement of financial position .

The MTB ratio will be greater than one if the accounting system reduces the book value of net assets from the market value, which is an indicator of the practice of accounting reservation in testing the impact of disclosure of the dimensions of sustainable development on the quality of financial reports in Iraqi commercial banks.

\section{Study model}

Based on the above presented of the study problem, its goals, and its assumptions, the study model was developed to measure the impact of the disclosure of the dimensions of sustainable development (dependent variable) on the quality of financial reports (independent variable), as shown in Fig. 1:

\section{The dimensions of sustainable development}

The disclosure of the economic aspect

The disclosure of the social aspect

The disclosure of the environmental aspect

\section{The quality of financial reports}

Fig. 1. Study model

Based on the above, the following equation has been formulated to analyze the study model as follows:

$F R Q=\beta 0+\beta 1($ EcoDis $)+\beta 2($ Env.Dis $)++\beta 3($ SocDis $)+\varepsilon$

\section{Analysis of the study results}

The analysis of the results of the applied study was based on three stages that began with checking the validity of the data for statistical analysis, then a description of the study data, and ending with testing its hypotheses. The following is an analysis of those stages:

\subsection{Data validity test for statistical analysis}

The linear multiplicity test was examined by calculating the (Tolerance) parameter for each of the independent variables, and then finding the (Variance Inflation Factor-VIF) parameter as a measure of the effect of correlation between the independent variables. This can be illustrated by Table 1 .

\section{Table 1}

Multicollinearity Test

\begin{tabular}{ccc}
\hline Variables & Tolerance & the variance inflation factor (VIF) \\
\hline The economic dimension & 0.814 & 3.265 \\
The environmental dimension & 0.741 & 2.214 \\
The social dimension & 0.641 & 1.426 \\
\hline
\end{tabular}

It is clear from Table 1 That the value of (VIF) for all study variables did not exceed (10). According to (Sabir et al, 2019; Field, 2005) if VIF did not reach 10 that means, the study model does not suffer from the problem of linear interference, as the 
correlation between the variables has no statistical significance and is very low, and this indicates the strength of the study models in interpreting and determining the effect on the dependent variable.

\subsection{Descriptive analysis of variables}

After verifying the validity of the data for statistical analysis, the second stage comes in which an analytical description of the study variables as it is shown in Table 2 below:

Table 2

Descriptive statistics of the study variables

\begin{tabular}{lrcccc}
\hline \multicolumn{1}{c}{ Variable } & Frequency & Lowest Value & Average & Highest Value & Standard Deviation \\
\hline \multicolumn{1}{c}{ Quality of financial reports } & 91 & .452 & 1.00 & 2.441 & 0.417 \\
Disclosure of the economic dimension & 91 & 56.724 & 61.051 & 100 & 11.978 \\
Disclosure of the environmental dimension & 91 & 3.680 & 12.580 & 82.241 & 20.812 \\
Disclosure of the social dimension & 91 & 11.140 & 14.917 & 54.647 & 10.287 \\
\hline All dimensions & 91 & 13.174 & 18.814 & 67.914 \\
\hline
\end{tabular}

Table 2 presents the descriptive statistics of the study variables related to (13) commercial banks listed in the Iraq Stock Exchange for the period (2012-2018):

1. The dependent variable (the quality of financial reports) has reached the lowest percentage (0.452) for the Iraqi Bank (AlMal) in (2017), and the highest quality of financial reporting (2.441) for the (Al-Eskan) Bank for Trade and Finance in (2018), and the average The quality of financial reports (1.00), and when the MTB ratio is greater than one, it is considered an indicator of the practice of accounting reservation. But it is noticeable that there is a gap between the banks in adopting the reservation policy.

2. The average disclosure of the economic dimension in Iraqi commercial banks during the period (2012-2018) was (61.051\%), and with a standard deviation of $(11.978 \%)$. While the largest value recorded during the period is $(100.00 \%)$, and the lowest value was $(56.724 \%)$. This indicates the interest of commercial banks in disclosing information about economic and financial performance.

3. The average disclosure of the environmental dimension in Iraqi commercial banks during the period (2018-2018) was $(12.580 \%)$, and with a standard deviation of $(20.812 \%)$. While the largest value recorded during the period is $(82.241 \%)$, and the lowest value was $(3,680 \%)$. The disclosure of the environmental dimension in commercial banks is low, because the operations of the banks do not contradict the environment, and the disclosures are limited to the bank's contributions to local environmental affairs and energy consumption.

4. The average disclosure of the social dimension in Iraqi commercial banks during the period (2012-2018) was (14.917\%), and with a standard deviation of $(10.287 \%)$. While the largest value recorded during the period is $(54.647 \%)$, and the lowest value was $(11.140 \%)$. Disclosure of the social dimension appeared in low percentages in many banks, where disclosures were concentrated in activities related to workers and clients. Disclosures related to products and contribution to societal affairs decreased, and human rights disappeared in many banks.

5. The average total disclosure of the dimensions of sustainability in Iraqi commercial banks during the period (2012-2018) was $18.814 \%$ and with a standard deviation of $13.499 \%$. While the largest value recorded during the period is $(67.914 \%)$, and the lowest value was (13.174\%). This study notes that commercial banks, in general, did not reach a significant level of disclosure of the dimensions of sustainability. The level of disclosure of the economic dimension was the highest, followed by the disclosure of the social dimension, then the disclosure of the environmental dimension. This may be explained by the interest of banks in disclosing the economic aspects that increase the level of confidence in their performance by owners, investors, and current and prospective clients of the bank. On the other hand, the increase in the level of disclosure of the social dimension at the level of disclosure of the environmental dimension may be explained by the bank's desire to confirm the bonds of the social contract with members of society and its contribution to aspects of community development in a manner that exceeds its interest in environmental affairs.

\subsection{Hypotheses testing}

The common regression model was used in the form of the regression model to measure the impact of the independent variable (disclosure of the dimensions of sustainable development) on the dependent variable (the quality of financial reports in Iraqi commercial banks), and Table 3 presents the results of the regression analysis. 
Table 3

Regression Analysis Results

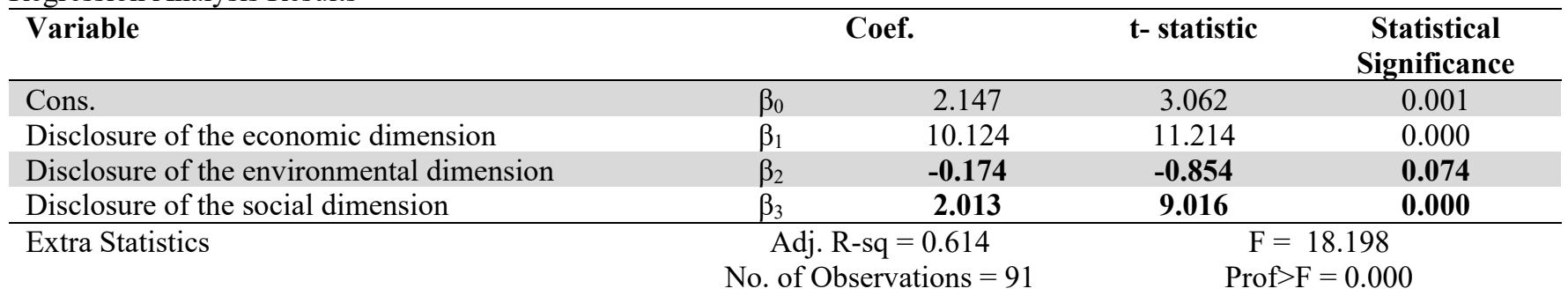

The results show that the value of $(\mathrm{F})$ is $(18.198)$ and the value of $(\mathrm{F}$. sig $=(0.000)$, which indicates that the model is highly significant and statistically significant and that the value of Adjust $\left(\mathrm{R}^{2}\right)$ is $(0.614)$, which reflects that the explanatory value of the model is high as most of the variables can be explained through the model. Therefore, the disclosure of the dimensions of sustainable development affects positively the quality of financial reports in commercial banks and their ability to contribute and improve the quality of financial reports in commercial banks.

The effect of independent variables separately (each of them) on the quality of financial reports in commercial banks shows the followings:

First, the disclosure of the economic dimension, the results of regression analysis through Table 3 showed that the regression coefficient signal $(\beta)$ is positive $(10.124)$ and that the value of $(\mathrm{Sig}=0.000)$ is less than the significance level $(0.05)$, which indicates the presence of a significant effect of a variable (Disclosure of the economic dimension) on the quality of financial reports in Iraqi commercial banks, which proves the validity of the first hypothesis.

Second, the disclosure of the environmental dimension, the results of the regression analysis showed that the regression coefficient signal $(\beta)$ is negative $(-0.174)$ and the value of $(\mathrm{Sig}=-0.074)$ is greater than the significance level $(0.05)$, which indicates that there is no significant effect of disclosure of the environmental dimension on the quality of financial reports in Iraqi commercial banks, which proves the incorrectness of the second hypothesis.

Third, the disclosure of the social dimension, the results of regression analysis through Table 3 showed that the regression coefficient signal $(\beta)$ is positive $(2.013)$ and that the value of $(\mathrm{Sig}=0.000)$ is less than the significance level $(0.05)$, which indicates the presence of a significant effect of a variable (The disclosure of the social dimension) on the quality of financial reports in Iraqi commercial banks, which proves the validity of the third hypothesis.

Based on the results of Table 3 above, the regression model can be formulated as follows:

$$
F R Q=2.147+10.124(\text { EcoDis) }-0.174(\text { Env.Dis })++2.013 \text { (SocDis) }
$$

\section{Discussion}

1- The results of the study showed that Iraqi commercial banks are interested in disclosing information on economic and financial performance as banks seek to achieve economic growth, economic welfare, and their presence in the market. This result coincided with a study by Laptes and Sofian (2016) which concluded that banks operating in Iraq give more priority to disclosing the economic dimension, rather than the social and environmental dimensions.

2- The results showed a low level of disclosure of the environmental dimension in Iraqi commercial banks, due to the nature of their work based on financial aspects, in addition to the fact that the activities of banks do not affect natural resources. The disclosures of the bank's contributions are limited to local environmental affairs and energy consumption, and this corresponds to the result of the study by Dhaimesh and Zobi (2019) which confirmed the banks have a lack of interest on the environmental dimension.

3- The results indicate a low level of disclosure of the social dimension in Iraqi commercial banks, and the disclosures focused on activities related to workers and customers, given the great benefit that banks achieve from paying attention to these two elements, which are positively reflected on their financial goals and growth. This finding was consistent with the study of Platonova, et al., 2018 that banks are interested in the social dimension.

4- Results showed that the level of accounting reservations in the financial reports was medium, there is a gap among banks in following the accounting reservation policy, and this affects the spread of banks in markets and the size of the bank. This result 
is similar to the result of Inkiläinen (2017), which indicated that there is a positive and important relationship between the accounting reservation and the fair value of firms.

5- Results have proven that disclosure of the dimensions of sustainable development as a whole has a positive impact on the quality of financial reports in commercial banks. R square which is $61.4 \%$ explains the quality of financial reports, and this indicates that commercial banks that disclose the dimensions of sustainable development can contribute and improve the quality of their financial reports. This result is similar to the result of Malo-Alain et al. (2019), which indicated that there is a positive and important relationship between the accounting disclosure of sustainable development and the quality of financial reports through the accounting reservation scale. The increase in the disclosure of sustainability leads to an expansion in the value of the accounting reservation. Similarly, Rusady \& Prasetyo (2018) indicate that the disclosure of all dimensions of sustainable development as one package positively affects the reliability of accounting information in banks.

6- The results showed that there is a positive moral effect of the variable disclosure of the economic dimension and the disclosure of the social dimension on the quality of financial reports in Iraqi commercial banks, and this is similar to the results of (Rusady \& Prasetyo, 2018).

7- The results showed that there was no significant effect of the disclosure of the environmental dimension on the quality of financial reports in Iraqi commercial banks and this was similar to Al-Ani et al (2018) results.

\section{9- Conclusion}

The effect of disclosure of the three dimensions of sustainable development (economic, social, and environmental) has been tested on the banks' performance through the issuance of sustainability reports. The results of the study showed the interest of Iraqi commercial banks to disclose information on economic and financial performance as banks seek to achieve economic growth, economic well-being, and their presence in the market. Furthermore, it has been found in this study that, there is a low level of disclosure of the environmental and social dimension in Iraqi commercial banks in view, but there is a moral impact of these two elements on the quality of financial reports. Our results prove that disclosure of the dimensions of sustainable development as a whole has a positive impact on the quality of financial reports in commercial banks in Iraq. The paper recommends conducting more research and studies on the dimensions of sustainable development in the future for other sectors such as industrial and service sectors linking it with other variables such as the cost of capital, or inconsistency of information.

\section{References}

Ahmed, D. M., \& Al-Kake, F. (2019). Application of accrual basis in the public sector and its role in providing useful information exploratory study of a sample of academic specialists in the Kurdistan Region of Iraq. Qalaai Zanist Journal, 4(1), 1012-1049..

Al-Ani, T. A., Vaddadi, K. M., \& Surarchith, N. K. (2018). The analysis of corporate social responsibility in one of the private universities in Kurdistan Region of Iraq. Archives of Business Research, 6(2).

Abdullah, R., \& Jaf, S. (2015). The role of mark to market on the properties of accounting information in Kurdistan International Bank. Research Journal of Finance and Accounting, 6(4), 181-195.

Abdullah, R., Jaf, S., \& Xinping, X. (2011). Possibility Realized Competitive Advantage By Strategic Information Systems Evidence From Iraqi Banks (No. 2011-020-151). Conference Master Resources.

Jaf, R. A., Sabr, S. A., \& Nader, K. A. (2015). Impact of management accounting techniques on achieve competitive advantage. Research Journal of Finance and Accounting, 6(4), 84-99..

Jaf, R. A. S., Xinping, X., \& Jaf, S. A. S. (2012, January). The effect of the Strategic Information Systems (SIS) on the achievement competitive advantage practical in samples of iraqi banks. In 2012 Second International Conference on Intelligent System Design and Engineering Application (pp. 954-959). IEEE.

Ibrahim, S. A. (2015). The Impact of Foreign Direct Investment on Economic Growth in Nigeria. Information Management and Business Review, 7(4), 90-97.

Baban, \& Hasan, N. N. (2019). Impact of the foreign direct investment on the economy of the United Kingdom. International Journal of Psychosocial Rehabilitation, 23(2), 743-763. https://doi.org/10.37200/IJPR/V23I2/PR190328

Hasan, N., Omer, A. J., Othman, B., Perot, K. A., Majid, A. A., \& Kareem, F. A. (2019). Macroeconomic determinates of stock price for industrial companies listed in istanbul stock exchange. International Journal of Psychosocial Rehabilitation, 23(2), 947-963. https://doi.org/10.37200/IJPR/V23I2/PR190342

Ogiemwonyi , Hamawandy, H. (2020). The relationship between service quality dimensions and customer satisfaction towards hypermarket in Malaysia. International Journal of Psychosocial Rehabilitation, 24(5), 2062-2071. https://doi.org/10.37200/ijpr/v24i5/pr201904

Ogiemwonyi, O., Harun, A., Othman, B., Ismael, D., Alam, M. N., \& Hamawandy, N. M. (2020). Analyzing Issues and Challenges on Environmentally Supportive Behaviour Among Malaysian and Nigerian Consumers. Sci.Int.(Lahore), ISSN 
Shezad, H., \& Omer, R. (2020). Role of internal and external audit in public sector governance. A case study of Kurdistan regional government. International Journal of Advanced Science and Technology, 29(8 Special Issue), $1452-1462$.

Albu, N., Albu, C. N., Gĭrbină, M. M., \& Sandu, M. I. (2011). The implications of corporate social responsibility on the accounting profession: The case of Romania. Amfiteatru Economic, 13(29), 221 -234.

AL-Kake, F. R. A. (2019). Problems of Internal Auditing in the Educational Sector.

Al-kake, F. A. K., \& Ahmed, D. M. (2019). The role of the Sarbanes-Oxley Act (Sox) in reducing agency costs exploratory study of a sample of auditors in the Kurdistan Region of Iraq. Qalaai Zanist Journal, 4(2), 637-673.

Annual Financial Reports (2012-2018) from Iraqi commercial banks listed in Baghdad Stock Exchange available at http://www.isx-iq.net/isxportal/portal/homePage.html.

Aras, G., \& Crowther, D. (2009). Corporate sustainability reporting: a study in disingenuity?. Journal of Business Ethics, 87(1), 279.

Barth, M. E., Landsman, W. R., \& Lang, M. H. (2008). International accounting standards and accounting quality. Journal of Accounting Research, 46(3), 467-498.

Beest, F. V., Braam, G. J. M., \& Boelens, S. (2009). Quality of financial reporting: Measuring qualitative characteristics. Nijmegen Center for Economics (NICE) Working Paper, 9 (108), 1-41.

Cheung, E., Evans, E., \& Wright, S. (2010). An historical review of quality in financial reporting in Australia. Pacific Accounting Review, 22(2), 147-169.

Dhaimesh, O. H., \& Al Zobi, M. K. (2019). The effect of sustainability accounting disclosures on financial performance: an empirical study on the Jordanian banking sector. Banks and Bank Systems, 14(2), 1- 8.

Dixit, P., Al-Kake, F., \& Ahmed, R. R. (2019). A critical review over the role of micro-finance institution and its relevance in Growing Indian Economy. Russian Journal of Agricultural and Socio-Economic Sciences.

Field, A. (2009). Discovering statistics using SPSS:(and sex and drugs and rock'n'roll). Sage.

Goel, S. (2012). Financial reporting-the old age tussle between legality and quality in context of rarnings Management. Procedia Economics and Finance, 3, 576-581.

Hamdan, A. M. M., Abzakh, M. H., \& Al-Ataibi, M. H. (2011). Factors influencing the level of accounting conservatism in the financial statements. International Business Research, 4(3), 145-155.

$\mathrm{Hu}$, J., Li, A. Y., \& Zhang, F. F. (2014). Does accounting conservatism improve the corporate information environment?. Journal of international accounting, Auditing and Taxation, 23(1), 32-43.

Inkiläinen, Z. A. (2017). The effect of accounting conservatism and its impacts on the fair value of the corporation. Middle East Comprehensive Journal For Education And Science Publications (MECSJ), 62.

Jaf, R. A., Shatnawi, H. \& Al-Kake, F. (2019). The impact of strategic analysis for operating income on the performance evaluation case study on Baghdad soft drink company. International Conference on Accounting, Business, Economics and Politics, ICABEP, 414-423.

Kevin, K., \& Vicki, W. (2008). Earnings Quality and Future Capital Investment: Evidence from Discretionary Accruals. Haas School of Business University of California at Berkeley, Mcdonough School of Business Georgetown University, no line Avalable at: www. ssm. com.

Laptes, R., \& Sofian, I. (2016). A new dimension of the entities' financial reporting: Integrated Reporting. Bulletin of the Transilvania University of Brasov. Economic Sciences. Series V, 9(2), 239.

Malo-Alain, A. M., Melegy, M. M. A. H., \& Ghoneim, M. R. Y. (2019). The effects of sustainability disclosure on the quality of financial reports in Saudi business environment. Academy of Accounting and Financial Studies Journal, 23(5).

Moneva J.M., ArchelP and Correa, C. (2006). GRI and the camouflaging of corporate unsustainability. Accounting Forum, 30 (2), 121-137.

NawzadSabir, M., Othman, B., Kake, F. A., \& Rashid, W. (2019). The Influence of Entrepreneurship Characteristics on Attitude towards Knowledge Commercialization. International Journal of Psychosocial Rehabilitation, 23(02).

Othman, B. J., Al-Kake, F., Diah, M. L. M., Othman, B., \& Hasan, N. M. (2019). This study examines the antecedents and the effects of knowledge management and information technology in the manufacturing industry. International Journal of Psychosocial Rehabilitation, 23(02).

Platonova, E., Asutay, M., Dixon, R., \& Mohammad, S. (2018). The impact of corporate social responsibility disclosure on financial performance: Evidence from the GCC Islamic banking sector. Journal of Business Ethics, 151(2), $451-471$.

Rusady, W. P., \& Prasetyo, A. B. (2018). Effect of corporate governance and disclosure of corporate social responsibility on the quality of financial statements. InFestasi (Journal Bisnis dan Akuntansi), 14(2), 146-153.

Sabir, M. N., Rashid, W. N., Al-Kake, F., \& Othman, B. (2019). Entrepreneurship characteristics and attitude towards knowledge commercialization: Evidence from Malaysia. International Journal of Psychosocial Rehabilitation, 23(02).

Sebhatu, S. P., \& Enquist, B. (2007). ISO 14001 as a driving force for sustainable development and value creation. The TQM Magazine, 19(5),

Simnett, R., Vanstraelen, A., \& Chua, W. F. (2009). Assurance on sustainability reports: An international comparison. The Accounting Review, 84(3), 937-967.

Xio and Min. (2011). The quality of financial reporting in China: An examination from an accounting restatement perspective 


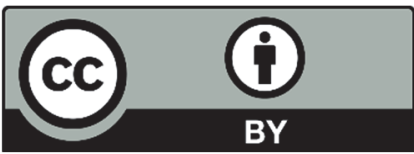

(C) 2021 by the authors; licensee Growing Science, Canada. This is an open access article distributed under the terms and conditions of the Creative Commons Attribution (CC-BY) license (http://creativecommons.org/licenses/by/4.0/). 